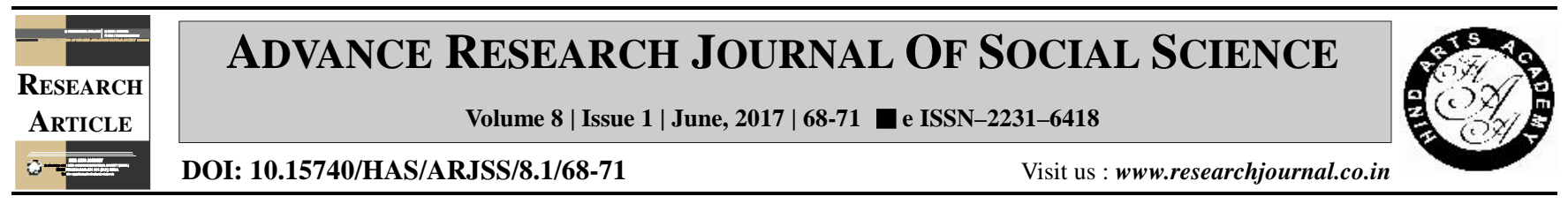

\title{
Factors associated with the plight of elderly
}

Leena Kumar and Seema Dey*

University Department of Home Science, Ranchi University, RANCHI (JHARKHAND) INDIA

(Email: seemade@ rediffmail.com)

\section{ARTICLE INFO :}

$\begin{array}{lll}\text { Received } & : & 20.02 .2017 \\ \text { Revised } & : & 03.05 .2017 \\ \text { Accepted } & : & 18.05 .2017\end{array}$

\section{KEY WORDS :}

Elderly, Association, Factors, Plight

\section{HOW TO CITE THIS ARTICLE :}

Kumar, Leena and Dey, Seema (2017).

Factors associated with the plight of elderly. Adv. Res. J. Soc. Sci., 8 (1) : 68-

71, DOI: 10.15740/HAS/ARJSS/8.1/68-

71.

*Author for correspondence

\begin{abstract}
In human life, the second stage is very critical period and needs a lot of adjustment. For comfortable and constructive role of old age, modern society is more concerned about the problems of retirement and aging. The elderly should realize that aging period is a development with its particular tasks such as keeping in touch with children, role of grandparents, engaged in certain activities and making close relations with one's mate. Everything is achieved by the person's own effort but the society also has some duty toward its old people. Earlier old people were unwilling to move to old age home for institutional care. Their families also were not willing to place their elderly in old age homes due to cultural norms. But now situation is changing gradually and for the elderly old age home is becoming more common. The present study was designed to find out the role played by family, society and factors associated with the plight of old age people. A sample of 200 senior citizens (above 60), 100 from old age homes and 100 from their own homes, were selected. The result shows that the family, society economical condition, illness, generation gap and selfishness are main factors for the most pathetic situation of old age people in India.
\end{abstract}

